Middle East Journal of Agriculture Research

EISSN: 2706-7955 ISSN: 2077-4605

DOI: 10.36632/mejar/2020.9.4.83
Volume : 09 | Issue : 04| Oct.-Dec. | 2020

Pages: 1066-1078

\title{
Maximizing Utilization of Bio-Fertilizers Immobilized on Bio-Char to Improve Bio- Characterization of Stevia Plant (Honey Leaves)
}

\author{
Azza A. Abd el Aal, Heba Sh. Shehata and Naayem M. Elgaml
}

\author{
Soils, Water and Environment Research Institute, Agriculture Research Center, Giza, Egypt.
}

Received: 15 Oct. 2020 / Accepted 20 Dec. 2020 / Publication date: 30 Dec. 2020

\begin{abstract}
The ruler goal of the current study is to determine the effect of organic fertilizer represented in bio-char that loaded by both inorganic nitrogen as (ammonium sulphate) and biofertilizer strains (Azotobcter chrococcoum, Bacillus subtilis, Pseudomonas fluorescents, Spirulina latensis and Anabaena azollae), in comparison with recommended fertilizer represented in (NPK), on biochemical composition, nutritional and therapeutic values of bio-sweetener Stevia (honey leaves). The promising data were obtained during the 30,60, 90 days after transplanting represented in growth parameters which include plant tallness, leaves number per plant, leaf area and leaf area index. Total chlorophyll content, moisture content, ash, protein, fats, total dietary fiber, and total carbohydrates, amino acid contents, macro and micro, fatty acids and vitamins which were determined. Bio-fertilizer strains immobilized by bio-char were ameliorated the nutritional characteristics. Data lead to employ bio-fertilizers immobilized on biochar for large scale because of low cost, high efficiency and easy in employ. In summing up, it can be used bio-char as an organic fertilizer, natural soil conditioner, safety ecosystem fertilizers could acquisition for high economic profits and multiple returns for the ecosystem and producers.
\end{abstract}

Keywords: Stevia Plant, growth parameters, chemical composition, biochar, biofertilizers.

\section{Introduction}

Stevia rebaudiana Bertoni is a branched wild hedge plant of the Asteraceae family (sunflower) and native in South America (Kamal, 2018), Stevia is well-known for its high content of sweet components. Chlorophylls, xanthophylls, flavonoids, alkaloids, hydroxycinnamic acids, oligosaccharides, free sugars, amino acids, lipids and trace elements are the components of dry extract of its leaves (Zayova et al 2013). Crude leaf extract of Stevia is utilized in soy sauce, various drinks, soju, yogurt, and different foods in some countries (Rai et al 2013; Serio, 2010). Stevia rebaudiana has grown to be quite well-known over a broad range of many areas and can in fact be productively grown under dissimilar conditions (Qui et al., 2000). Since plant cultivation is affecting the chemical sonata of leaves extracts, it has become the focal point of numerous research topics. Stevia is recognized to be in any case 50 - 100 eras sweeter than sucrose (Tadhani and Subhash, 2006) and it is a common substitute to various artificial sweeteners that do not offer the practical taste of sugar as well as some kinds of imitation sweeteners, such as saccharin which is correlated with the probable danger of bladder cancer (Rai et al., 2013).

Stevia plant is deemed a significant alternative natural sugar about artificial sugars for diabetic people because of it contain the main diterpene glycosides such as stevioside and rebaudioside that accountable about the sweet taste in Stevioside rebaudioside (Singh et al., 2019).

Prominence of Stevia plant is due to a widespread pharmaceutical effect as anti-bacterial, anti-fungal, anti-inflammatory, antimicrobial, antiviral, anti-yeast, cardio tonic, diuretic, hypoglycemic, hypotensive tonic, and vasodilator effect because of its include an vital source of a number of antioxidants, for example, benzoic acid, caffeic acid, chlorogenic acid, ferulic acid, rozmaric acid, protocatechuic acid, salicylic acid, and their derivatives and flavonoids including campherol derivatives, catechin, and its derivatives, epicatechin, luteolin, and its derivatives, rutin, and its derivatives (Jyoti et al.,2018).

Capability of bio-char is due to its utilization in environment management and as a sorbent for a few environmental contaminants, including heavy metals (Reddy et al., 2014a). Bio-char is produced from feedstock such as agricultural wastes, animal manures and paper products. The importance of these wastes for the production of biochar is an efficient way to turn waste to useful and value-added 
substance (Brewer et al., 2014). Pyrolysis is a thermochemical technology for transforming biomass into bio-char, bio-oil and syngas between 350 and $700{ }^{\circ} \mathrm{C}$ temperature in the absence of air (Varma et al., 2018). The physiochemical properties of bio-char are responsible for shifting soil description plus changes in $\mathrm{pH}$, nutrient preservation, and water retention, which can promote heterogeneous responses in microbial species that cause changes in microbial community structure and modify soil element cycling and function (Zhu et al., 2017).

Influencing of bio-char for improving microbial methane oxidation due to its sorption characteristics, steadiness in soil and high internal micro-porosity (Reddy et al., 2014b). The production conditions and post-production treatments applied are controlled by the physiochemical properties of the source materials and which play an important role in scheming properties of the resultant bio-char, (Kloss et al., 2012). Additionally, the temperature and length of heat treatment are the key production calculating elemental constituents of innovative feedstock composition. Escalating heat temperatures treatment enhance in surface area with boost in sorption of organic chemicals and degree of carbonization of bio-char increases, subsequent by declining $\mathrm{H}$ : $\mathrm{C}$ and $\mathrm{O}$ : $\mathrm{C}$ ratios and amorphous organic matter within it (Cabrera-and spokes, 2011 and Uchimiy et al., 2011). Some components in biochar, including minerals, volatile organic compounds (VOCs), and free radicals, can potentially control microbial action, reshape the soil microbial community, and alter the soil enzyme activity that catalyzes a variety of biogeochemical routes together with soil organic matter turnover and elemental cycles as nitrogen, phosphorus and sulphur (Paz-Ferreiro et al., 2014).

Bio-fertilizer is valuable replacements to inorganic fertilizers which advances the soil quality. By applying fertilizers good quality, high yielding planting store material can be produced; these fertilizers can be enormously advantageous for farmer with small participation of cost exactingly in developing countries. Efficient utilization of nitrogen is a vital target in crop management. One of the new successes is using bio-fertilizer which delays nitrification process for enough prolonged time and augments the soil fertility (Panel, et al., 2020). Incorporated nutrient management by using chemical and bio-fertilizer is found to increase yield of Stevia (Asteraceae). Hence, it was chosen to study the effect of chemical organic bio-char loaded nitrogen and bio-fertilizers on the morphological characters, protein content and carbohydrate within tissues of Stevia. Bio-fertilizers are those bodies that hold living micro-organisms and they colonized the area around the roots of the plant and augment the deliver or primary nutrients accessibility or/and growth motivation to the end crop (PGPR). The microorganisms employed for bio-fertilizers are bacteria Bacillus, Pseudomonas, Lactobacillus, photosynthetic bacteria, nitrogen fixing bacteria and fungi Trichoderma and yeasts which have the capability to activate plant nutrients in soil from ineffectual to utilizable type during microbiological process (Ismail et al., 2014). The plant growth promotion by microorganisms rendered to the chemical substance generated from plant and cooperated with some metabolites of microorganisms which applied as nitrogen fixers, phosphate dissolver, and fight of some phyto-pathogen and resist some non-fitting environmental conditions (Nilde et al., 2017).

Cyanobacteria are photosynthetic prokaryotes and colonizing microorganisms that are found all over the world and they are remarkably well adjusted to broad groups of environmental conditions. They can directly and/or indirectly boost the plant growth. The direct ways for production of plant growth promoting biologically as active substances including phytohormones like auxin, gibberellins and cytokinins (Zahra et al., 2020).

Depending on stability and fertility of biochar basic nano particles that might be used as safety soil amendment, climate changes mitigation, source of fertilizer and eco-friendly (Hassan et al., 2020). The present research aimed to examine bio-char loaded ammonium sulphate and biofertilizer strains (Azotobcter chrococcoum, Bacillus subtilis, Pseudomonas fluorescens, Splrulina platensis and Anabaena azollae), in comparison with complex chemical fertilizers represented by(NPK), on sandy soil physical and chemical characteristics, biochemical composition, nutritional and therapeutic values of bio-sweetener Stevia (honey leaves). 


\section{Materials and Methods}

The experiment was conducted at the farm of research station Cairo University, Faculty of Agriculture, Wadi El-Natron Behera Governorate. The seedlings of Stevia rubidian sprouts were purchased from faculty of pharmacy Cairo Univ., and grown in sandy soil. The plantation was done in winter season in $15^{\text {th }}$ November 2018 and was harvested in 1 September 2019. The characteristics of soil were coarse sand $13.2 \%$, sand $-80.60 \%$, Silt $3.2 \%$, Clay 3\% (sandy texture), Organic Carbon o.34\%, available Sulphur $0.002 \%$, Nitrogen $0.005 \%$, Phosphorous $4.2 \%$ and Potassium $117.0 \mu \mathrm{g} / \mathrm{g}$, soil pH 7.89, EC $1.23 \mathrm{dS} / \mathrm{m}$ according to Jackson, (1973) and Richards, (1954) soil reaction (pH) in 1:1 (w: v) soil: water suspension by $\mathrm{pH}$ meter; electrical conductivity $\left(\mathrm{EC} 25^{\circ} \mathrm{C}\right)$ in the same soil suspension by EC meter. The field experimentation was arranged out in a completely randomized design with three replications. The randomized block system was tracked with three replications and five treatments, in total 15 experimental plots. The size of each experimental plot was $\left(50 \mathrm{~m}^{2}\right)$. Spacing systems were used $(60 \times 20 \mathrm{~cm}$.) between rows and plants. The measurements of vegetative parameters were in use after 30 , 60 and 90 days from transplanting just in time for harvest. The ideal time to harvest the Stevia leaves is when the flowering starts. The technique to harvest is whichever by hand or by machine. Over the surface of the ground by $5 \mathrm{~cm}$. the plants were cut and at once were transmit to exposure for the natural dryer (sun) for 3 days, after that was the separation of the dried leaves from the stems which is much easier than the traditional method, where we separate the green leaves from the green stem.

The five treatments as follow:

T1: Control (NPK, Complex, fertilizer).

T2: Bio-char loaded nitrogen (ammonium sulphate).

T3: Bio-char loaded (Azotobcter chrococcoum + Bacillus subtilis + Pseudomonas fluorescens)

T4: Bio-char loaded (Spirulina platensis + Anabaena azollae)

T5: Bio-char loaded all strains (Azotobcter chrococcoum + Bacillus subtilis + Pseudomonas fluorescens + Spirulina platensis and Anabaena azollae).

\section{Sample preparation of bio-char}

After cut rice husk into small parts $(4.00-5.00 \mathrm{~mm})$, the pyrolyzing rice husk in oven at $350^{\circ} \mathrm{C}$ for 24 hours to derive bio-char. Chemical properties and composition of rice husk derive bio-char are represent in Table 1. The contents of Ash, carbon, nitrogen, and hydrogen according to (Kinney et al., 2012) Bio-char reaction $(\mathrm{pH})$ in 1:1 (w: v) biochar water suspension by $\mathrm{pH}$ meter; electrical conductivity $\left(\mathrm{EC} 25^{\circ} \mathrm{C}\right)$ in the same bio-char suspension by EC meter. Silica, $\mathrm{Ca}, \mathrm{K}, \mathrm{Mg}$ and $\mathrm{S}$ were measured by atomic adsorption Spectrophotometer with air-acetylene, fuel (Pye Unica, model SP-1900, US). Zeta potential (ZP) was measured for bio-char by Zeta-Meter 3.0+ system (Zeta Meter Inc., VA) at National Research Center. Giza, Egypt: $\mathrm{N}$ ratios after soaking in ammonium sulphate and after inoculation by microorganism were calculated.

\section{Preparation of Azotobacter chroococeom, Bacillus Subtilis and Pseudomonas fluorescence strains for loading bio-char}

Azotobacter chrococcoum, obtained from Department of Agricultural Microbiology, Soils, Water and Environment Research Inst., Agric. Res. Center (ARC), Giza, Egypt. Bacillus subtilis and Pseudomonas fluorescence were propagated on King'medium (King et al., 1954) while Azotobacter chrococcoum was cultured on adapted Ashby's media (Abd El-Malak, and Ishac, 1968). Liquid cultures of $A$. chrococcoum $\left(10^{7} \mathrm{CFU} / \mathrm{ml}\right.$.) in $250 \mathrm{ml}$. conical flasks were grown on adjusted Ashby' s medium for five days at $28-30{ }^{\circ} \mathrm{C}$.

\section{Bacillus Subtilis and Pseudomonas fluorescence strains}

Active strains were cultured on King's media (King et al., 1954), then gently shake on a rotary shaker incubator at $30{ }^{\circ} \mathrm{C}+/-2{ }^{\circ} \mathrm{C}$ up to attain the long phase $\left(10^{7} \mathrm{cfu} \mathrm{m}^{-1}\right.$. After set up amount of Azotobacter chroococcum, Bacillus Subtilis and Pseudomonas fluorescence strains and monitoring colonies growth of both strains in solution for $24 \mathrm{hr}, 48 \mathrm{hr}$. and three days. 
Table 1: Chemical properties and composition of rice husk derive bio-char

\begin{tabular}{|c|c|}
\hline \multirow{2}{*}{$\begin{array}{l}\text { Elements evaluated } \\
\text { Temperature }{ }^{0} \mathrm{C}\end{array}$} & Rice husk derive bio-char \\
\hline & $350^{\circ} \mathrm{C}$ \\
\hline $\mathrm{Si} \quad \mathrm{mg} / \mathrm{kg}$ & 179 \\
\hline Ca & 213 \\
\hline K & 199 \\
\hline Mg & 179 \\
\hline Water \% & 3.88 \\
\hline Ash\% & 47.90 \\
\hline pH & 7.65 \\
\hline Fixed C & 46.35 \\
\hline H $\quad$ (mg) & 2.64 \\
\hline $\mathrm{N} \quad(\mathrm{mg})$ as $\mathrm{N}_{2} \mathrm{O}$ after inoculation & 2.4 \\
\hline $\mathrm{N} \quad(\mathrm{mg})$ as $\mathrm{N}_{2} \mathrm{O}$ after soaking in ammonium sulphate & 3.65 \\
\hline $\mathrm{S} \quad(\mathrm{mg})$ & 0.22 \\
\hline O (mg) & 2.74 \\
\hline Volatile matter \% & ---- \\
\hline $\mathrm{H}: \mathbf{C}$ & 0.05 \\
\hline $\mathrm{C}: \mathrm{N}$ after inoculation by microorganism & 18.85 \\
\hline $\mathrm{C}: \mathrm{N}$ after soaking in ammonium sulphate & 12.92 \\
\hline EC $\quad(\mathrm{ds} / \mathrm{m})$ & 0.14 \\
\hline Zeta potential & $-26.6 \mathrm{mV}$ \\
\hline
\end{tabular}

\section{Algal starting place and growth situations:}

Anabaena azollae and Spirulina platensis were acquired from Department of Agricultural Microbiology, Soils, Water and Environment Res. Inst., ARC, Giza. Ananbaena azollae strain which isolated from Azolla pinnata (Abd El-Aal, Azza, 2013) was grown on BG11 medium (Rippka, et al., 1979) while Zarrouk medium was used for Spirulina platensis culture (Zarrouk, 1966). Cultures were kept warm in a growth cavity under permanent illumination (2000 lux), with temperatures of $\left(25^{\circ} \mathrm{C} \pm\right.$ $\left.2^{\circ} \mathrm{C}\right)$ and $\left(35^{\circ} \mathrm{C} \pm 2^{\circ} \mathrm{C}\right)$ for both Anabaena azollae and the mesophilic alga Spirulina platensis.

\section{Preparation Bio-char for loading nitrogen:}

Bio-char loading nitrogen was preparing by soaking bio-char in ammonium sulphate1 $\mathrm{M}$ solution for 4 days at $25^{\circ} \mathrm{C}$ according to ( $\mathrm{Li}$ et al., 2013). Total $\mathrm{N}$ content was analyzed using the Kjeldahl digestion method (Peach and Tracy 1956), air dried then was added before planting at rate (5 tons/hectare).

\section{Preparation Bio-char for loading bio-fertilizers:}

For loading by bio-fertilizers, biochar was soaked in strains media for two days, then high resolution scan microscope FE-SEM (Field Emission Scanning Electron Microscope), quanta FEG 250. Electron microscope unit, at National Research Center. Giza, Egypt, was used to manifest the growth of strains inside macro, meso, and micro pores of bio-char. Organic fertilizers (biochar) was added to sandy soil before planting and mixed well at the rate of 12 tons/ hectare for both biochar loading nitrogen and loading bio-fertilizers. The strains of bio- fertilizers were given to the seedlings after 20, 40, 60 days of plantation at the rate of $20 \mathrm{~L} / \mathrm{fed}$. for Azotobcter chrococcoum, Bacillus subtilis and Pseudomonas fluorescens. $50 \mathrm{~L} /$ fed. for Spirulina platensis and Anabaena azollae, and $35 \mathrm{~L} / \mathrm{fed}$. for the mixture of bacteria and algae. After plantlets plantation the drip uniform irrigation was provided and following when required. Inorganic fertilizers as control treatment NPK (Nitrogen: Phosphorus: Potassium, 18:18:10) were given as recommended by Ministry of Agriculture. Growth parameters such as height was measured in centimeters, number leaves, leaf area was measured in $\mathrm{cm}^{2}$ and leaves area index was measured. Total chlorophyll, protein content \& carbohydrate were resolute in third and fourth leaf from the top. The green fresh leaves were permit to dry under sun light for about 4 days. The dried leaves were then grinded to powder. The total nitrogen content was determined by using the modifiedmicro-Kjeldahel method of the dried powder as described by (Peach. and Tracy, 1956). By using the chlorostannous molybdophosphoric blue color method in sulphuric acid according to (Jackson, 1973). Phosphorus was determined. calorimetrically by the flame photometer apparatus (CORNING M 410, Germany). Potassium concentrations were determined by Atomic Absorption Spectrophotometer with 
air-acetylene, fuel (Pye Unicam, model SP-1900, US) to determine the concentration of $\mathrm{Na}, \mathrm{Mg}$, Fe and $\mathrm{Zn}$.

\section{Plant analysis:}

The prepared powder samples were examined for moisture, protein, fat, crude fiber and ash according to the methods described in the (AOAC, 2000).

Total carbohydrates in plant were determined by phosphomolybdic acid method according to AOAC, (1970).

Total chlorophyll was measured by fresh leaves which were extracted with dimethyl form amide and placed overnight at cool temperature $\left(5^{\circ} \mathrm{C}\right)$. Total chlorophylls were measured by Spectrophotometer at wavelengths 663,647 and $470 \mathrm{~nm}$, respectively. Chlorophylls were calculated according to the equation described by (Nornai, 1982).

$$
\text { Total Chl. }=17.90 \mathrm{~A}_{647}+8.08 \mathrm{~A}_{663}
$$

Table 2: Some characteristics of bio-fertilizers in the studied sandy soil.

\begin{tabular}{|c|c|c|c|c|}
\hline \multirow[t]{2}{*}{ Strains } & \multirow[t]{2}{*}{ N2-ase M.mole C2H4/m/hr } & \multicolumn{3}{|c|}{ Phytohormons $\mu \mathrm{g} / \mathrm{l}$ culture } \\
\hline & & IAA & Gibbrillic acid. & Cytokynine \\
\hline Azotobcter chrococcoum & 285.55 & 67.36 & 102.20 & 149.00 \\
\hline Bacillus subtilis & - & 192.00 & 861.09 & 200.60 \\
\hline Pseudomonas fluorescens & - & 163.00 & 510.20 & 217.50 \\
\hline Splrulina platensis & - & 15.13 & 97.65 & -196.2 \\
\hline Anabaena azollae & 186.15 & 19.85 & 87.80 & 186.16 \\
\hline
\end{tabular}

\section{Quantitative determination of endogenous phytohormones:}

The determination of cytokinins according to Plamer et al., (1981), for determination of gibberlic acid (GA), and indole-acetic acid (IAA) according to Fales and Jaouni (1973). Determination of nitrogenase using a colorimetric determination for ethylene according to Larue and kurz, (1973).

\section{Statistical analysis}

The obtained data were subjected to computer statistical software (COSTAT) originated by (Silva et al., 2009). The data were analyzed using ANOVA at 5\% significance level, the difference between treatments means then analyzed using DMRT (Duncan Multiple Range Test) at $5 \%$. (Duncan, 1955).

\section{Results and discussion}

\section{Vegetative parameters}

Table 3 show that the vegetative parameters of NPK complex fertilizer as control treatment(T1), (T2) bio-char loaded nitrogen, (T3) bio- char loaded mixture of (Azotobcter chrococcoum + Bacillus subtilis + Pseudomonas fluorescens), (T4) Bio-char loaded algae mixture (Spirulina platensis and Anabaena azollae), and (T5) bio-char loaded all previous strains

Vegetative parameters showed that plant tallness throughout the period of growth gave differences between all treatments. The T5 (bio-char loaded all strains of bio-fertilizers) was recorded high value, percentage of increases with the age of plant that was as follows $19.3 \%, 29.17 \% 46.9 \%$ through $30-60$ 90 day over control, respectively. In addition, data showed that the highest leaf number per plant was evidenced by treatment (T5) which reached two-folds compared to control at 90 date. Moreover, leaves area index was high significant in all of the plant periods among all treatments compared to the control. The results were agreement with (Aladakatti, et al., 2012). Application levels of nitrogen, phosphorus and potassium on growth and yield of stevia plant boosted plant height, number of leaves, leaves area, and leaves area index. The results were agreement with (Khiraoui et al., 2017) who illustrated that height, number of tillers, dry weight and grain yield of various plants augmented by inoculation with PGPR. Moreover, Piromyou et al., (2011) stated that the growth traits such as shoot and root lengths and yield properties of rice crop like plant height, number of tillers, number of panicle and grain weight were boosted by application of cyanobacteria. In addition, bio-fertilizers are important substitutions to inorganic fertilizers. One of bio-fertilizers' advantages is conquering nitrification process for prolong 
time and boosting the soil fertility (Bargaz et al., 2018). Incorporated nutrient management by chemical and bio-fertilizer is found to increase yield of Stevia plant. This is owing to their capability to fix atmospheric nitrogen symbiotically or no symbiotically and alternative soil nutrients like phosphorus, zinc, copper, iron, sulfur to functional form through biological processes which in turn releases nutrients by plants resulting in increase in biomass production of stevia plant (Glaser et al., 2002).

Table 3: Vegetative parameters of different treatments on Stevia plants.

\begin{tabular}{ccccccccccccc}
\hline Treatments & \multicolumn{4}{c}{ 30 DAT } & \multicolumn{1}{c}{ 60 DAT } & \multicolumn{4}{c}{ 90 DAT } \\
\cline { 2 - 12 } & H & NL & LA & LAI & H & NL & LA & LAI & H & NL & LA & LAI \\
\hline T1 & $13.59^{\mathrm{a}}$ & $11.17^{\mathrm{b}}$ & $67.90^{\mathrm{e}}$ & $1.19^{\mathrm{a}}$ & $22.45^{\mathrm{d}}$ & $31.32^{\mathrm{c}}$ & $190.45^{\mathrm{e}}$ & $1.79^{\mathrm{a}}$ & $39.00^{\mathrm{b}}$ & $110.79^{\mathrm{c}}$ & $420.12^{\mathrm{d}}$ & $0.63^{\mathrm{c}}$ \\
T2 & $14.15^{\mathrm{a}}$ & $12.65^{\mathrm{b}}$ & $75.65^{\mathrm{d}}$ & $1.21^{\mathrm{a}}$ & $23.51^{\mathrm{cd}}$ & $34.25^{\mathrm{c}}$ & $204.00^{\mathrm{d}}$ & $1.81^{\mathrm{a}}$ & $41.60^{\mathrm{b}}$ & $112.95^{\mathrm{c}}$ & $430.15^{\mathrm{c}}$ & $0.67^{\mathrm{bc}}$ \\
T3 & $14.45^{\mathrm{a}}$ & $12.75^{\mathrm{b}}$ & $78.61^{\mathrm{c}}$ & $1.26^{\mathrm{a}}$ & $24.13^{\mathrm{c}}$ & $47.23^{\mathrm{b}}$ & $302.00^{\mathrm{c}}$ & $2.06^{\mathrm{a}}$ & $56.10^{\mathrm{a}}$ & $255.19^{\mathrm{b}}$ & $641.17^{\mathrm{a}}$ & $1.28^{\mathrm{ab}}$ \\
T4 & $15.34^{\mathrm{a}}$ & $12.98^{\mathrm{a}}$ & $89.35^{\mathrm{b}}$ & $1.52^{\mathrm{a}}$ & $25.70^{\mathrm{b}}$ & $48.52^{\mathrm{ab}}$ & $308.00^{\mathrm{b}}$ & $2.10^{\mathrm{a}}$ & $57.16^{\mathrm{a}}$ & $254.00^{\mathrm{b}}$ & $635.17^{\mathrm{b}}$ & $1.24^{\mathrm{abc}}$ \\
T5 & $16.19^{\mathrm{a}}$ & $15.73^{\mathrm{b}}$ & $105.00^{\mathrm{a}}$ & $1.58^{\mathrm{a}}$ & $29.00^{\mathrm{a}}$ & $51.10^{\mathrm{a}}$ & $316.00^{\mathrm{a}}$ & $2.13^{\mathrm{a}}$ & $57.29^{\mathrm{a}}$ & $260.90^{\mathrm{a}}$ & $643.87^{\mathrm{a}}$ & $1.32^{\mathrm{a}}$ \\
\hline
\end{tabular}

$\mathrm{H}=$ Hight $/ \mathrm{cm}, \mathrm{NL}=$ number of leaves, $\mathrm{LA}=$ leafe area $\mathrm{cm}^{2}, \mathrm{LAI}=$ leafe area index, DAT=days after transplanting

\section{Total Chlorophyll of Stevia (honey leaves)}

Table 4 showed that variation of chlorophyll components between all treatments was occurred. The T5 (bio-char loaded mixture of bacteria and cyanobacteria) was recorded the high value of total chlorophyll during the periods 30, 60, and 90 days, tracked by T4, T3, T2. Mixture of bacteria and cyanobacteria increased the total chlorophyll significantly as mentioned with (Aladakatti et al., 2012) who found that implementation of $\mathrm{N}$ at 75 and $100 \mathrm{~kg} / \mathrm{ha}$ on Ocimum basilicum increased total chlorophyll and carotenoid contents. In addition, Godlewska et al. (2019) stated that cyanobacteria extract enhanced chlorophyll formation. Moreover, Richa et al., (2019) found that cyanobacteria and Azotobacter in different combination with chemical fertilization gave highest values of chlorophyll, likewise Amal et al., (2010) found that total chlorophyll of plant leaves responded positively to BGA (blue green algae) inoculation.

Table 4: The Effect of different treatments on the average of total chlorophyll of stevia (honey leaves).

\begin{tabular}{cccc}
\hline Treatments & \multicolumn{3}{c}{ Total Chlorophyll Content (mg g $\left.\mathbf{~}^{-1} \mathbf{d} . \mathbf{w}.\right)$} \\
\cline { 2 - 4 } & 30 DAT & 60 DAT & 90 DAT \\
\hline T1 & $3.09^{\mathrm{b}}$ & $3.78^{\mathrm{b}}$ & $4.10^{\mathrm{c}}$ \\
T2 & $3.15^{\mathrm{ab}}$ & $3.98^{\mathrm{b}}$ & $4.56^{\mathrm{bc}}$ \\
T3 & $3.24^{\mathrm{ab}}$ & $4.38^{\mathrm{ab}}$ & $4.90^{\mathrm{abc}}$ \\
T4 & $3.45^{\mathrm{a}}$ & $4.55^{\mathrm{ab}}$ & $5.10^{\mathrm{ab}}$ \\
T5 & $3.89^{\mathrm{a}}$ & $5.10^{\mathrm{a}}$ & $5.65^{\mathrm{a}}$ \\
\hline
\end{tabular}

DAT $=$ days after transplanting

\section{Carbohydrates}

Table 5 illustrated that the high value of carbohydrates was recorded with T5 (bio-char loaded all strains of biofertilizers) followed by T4, T3, and T2. Data are in conformity with (Glaser et al., 2002) who reported that combination of bio-fertilizer and chemical fertilizer boosted growth, chlorophyll, protein content and carbohydrates compared to control (NPK). Therefore, it is necessitated to evaluate and spread out a balanced fertilization strategy that amalgamates the use of chemical and organic or bio-fertilizers. Moreover, bio-char as a result of its capability to be employed in environmental management and as an adsorbent for some environmental impurities, involving heavy metals (Reddy and Dastgheibi, 2014a). Several essential responsibilities are due to carbohydrates in living beings. Therefore, monosaccharides are the main resource of power in human metabolism, while polysaccharides are the storage of energy and can perform as structural constituents. These compounds have also been linked to supplementary beneficial health properties. This includes a pre-biotic consequence plus added fewer widespread antioxidant or anti-provocative actions (Das et al., 2007). In addition, (Prathibha and Siddalingeshwara, 2013) mentioned that great function of carbohydrates in improving seed quality and nutritional quality by using PGPR strains such as $P$. fluorescence and $B$. subtilis

\section{Proteins}

Proteins, peptides and/or amino acids are established in a grand assortment of matrices counting animals, fungi, vegetables, cereals, etc. Das et al. (2007) classified eight vital amino acids in stevia 
leaves, i.e., glutamic acid, aspartic acid, lysine, serine, isoleucine, alanine, proline, tyrosine. In total seventeen amino acids were classified as essential and non-essential amino acids, involving arginine as one of the requisites was recorded significantly increase by T5 treatment as a resulting of the combination effect of bio-char loaded all strains of bio-fertilizers followed by T4, T3, and T2 over control treatment. Results coincided with (Gisleine et al., 2006) who reported that Stevia is recognized for its elevated substance of sweaty constituents. Flavonoids, alkaloids, chlorophylls, xanthophylls, hydroxyl cynnamic acids (caffeic, chlorogenic, etc), oligosaccharides, free sugars, amino acids, lipids and trace elements are the components of dry extract of its honey leaves. (Reddy and Dastgheibi. 2014a; Glaser, et al., 2002).

\section{Crude fiber}

Crude fiber values were arranged descendingly as follow: T5, T4, T3, T2, and T1. Dietary fibers are the edible parts of plants or equivalent carbohydrates that are opposed to digestion and absorption in the human small intestine while in the large intestine become with complete or fractional fermentation. In addition, a similar carbohydrate is termed as those carbohydrates-based food constituents that are non-digestible and non-absorbable, and which are similar to plant dietary fiber (Prosky 2001). Crude fiber has health payback for human as a result to involve an effective compound for cancer treating, supply as a substrate for colonic bacteria, encourages intestinal food transit, and decreases bile acid re-absorption by altering micelle formation and causative to minimizing blood cholesterol intensities (Sankhala et al., 2005).

Table 5: Analysis of dried Stevia leaves (g 100 g-1 dry weight basis.

\begin{tabular}{ccccccc}
\hline Treatments Components & Moisture & Protein & Fat & Ash & Carbohydrates Crude fiber \\
\hline T1 & $5.45^{\mathrm{c}}$ & $9.80^{\mathrm{b}}$ & $3.50^{\mathrm{c}}$ & $10.24^{\mathrm{c}}$ & $52.12^{\mathrm{b}}$ & $13.45^{\mathrm{b}}$ \\
T2 & $6.12^{\mathrm{bc}}$ & $11.00^{\mathrm{ab}}$ & $4.56^{\mathrm{b}}$ & $11.10^{\mathrm{bc}}$ & $57.25^{\mathrm{ab}}$ & $17.43^{\mathrm{a}}$ \\
T3 & $7.23^{\mathrm{ab}}$ & $11.69^{\mathrm{c}}$ & $5.09^{\mathrm{ab}}$ & $11.98^{\mathrm{ab}}$ & $58.56^{\mathrm{a}}$ & $18.50^{\mathrm{a}}$ \\
T4 & $8.12^{\mathrm{a}}$ & $12.00^{\mathrm{a}}$ & $5.45^{\mathrm{ab}}$ & $12.31^{\mathrm{a}}$ & $59.65^{\mathrm{a}}$ & $18.65^{\mathrm{a}}$ \\
T5 & $8.34^{\mathrm{c}}$ & $12.12^{\mathrm{a}}$ & $5.60^{\mathrm{a}}$ & $12.75^{\mathrm{a}}$ & $60.78^{\mathrm{a}}$ & $19.10^{\mathrm{a}}$ \\
\hline
\end{tabular}

Table 6 showed essential and non -essential amino acids which were affected by all treatments. The highest value of essential amino acids was recorded by T5 (bio-char loaded all strains of biofertilizers), tracked by T4, T3, T2 in comparison with T1 (control treatment), while non-essential amino acids were different trend. The highest value was recorded in T5 but the order of values in different between T4 or T3. Nots that all treatment gave significant increase over the control in (nonessential amino acids).

The results were agreement with (Mohammad et al., 2007) who categorized nine amino acids namely aspartic acid, glutamic acid, serine, lysine, isoleucine, proline, alanine, tyrosine and methionine in stevia leaves.

Table 6: Essential and non-essential weight basis amino acids content of stevia leaves (g $100 \mathrm{~g}$ dry).

\begin{tabular}{|c|c|c|c|c|c|c|c|c|c|}
\hline \multicolumn{10}{|c|}{ Essential amino acid } \\
\hline & Arginine & Lysine & Histidine & $\begin{array}{l}\text { Phenyl } \\
\text { alanine }\end{array}$ & Leucine & Methionine & Valine & Threonine & Isoleucine \\
\hline T1 & $0.43 \mathrm{a}$ & $0.23^{\mathrm{b}}$ & $0.32^{\mathrm{b}}$ & $0.67^{\mathrm{a}}$ & $0.83^{\mathrm{a}}$ & $0.93^{\mathrm{b}}$ & $0.61^{\mathrm{a}}$ & $0.74^{\mathrm{b}}$ & $0.46^{\mathrm{a}}$ \\
\hline $\mathbf{T} 2$ & $0.67^{\mathrm{a}}$ & $0.42^{\mathrm{ab}}$ & $0.48^{\mathrm{b}}$ & $0.72^{\mathrm{a}}$ & $0.89^{\mathrm{a}}$ & $1.17^{\mathrm{ab}}$ & $0.87^{\mathrm{a}}$ & $1.02^{\mathrm{ab}}$ & $0.57^{\mathrm{a}}$ \\
\hline T3 & $0.78 \mathrm{a}$ & $0.70^{\mathrm{a}}$ & $1.03^{\mathrm{a}}$ & $0.79^{a}$ & $0.96^{\mathrm{a}}$ & $1.35^{\mathrm{ab}}$ & $0.91^{\mathrm{a}}$ & $1.12^{\mathrm{ab}}$ & $0.71^{\mathrm{a}}$ \\
\hline T4 & $0.80^{\mathrm{a}}$ & $0.47^{\mathrm{ab}}$ & $0.97^{\mathrm{a}}$ & $0.80^{\mathrm{a}}$ & $1.12^{\mathrm{a}}$ & $1.25^{\mathrm{ab}}$ & $0.81^{\mathrm{a}}$ & $1.05^{\mathrm{ab}}$ & $0.74^{\mathrm{a}}$ \\
\hline T5 & $0.84^{\mathrm{a}}$ & $0.69^{a}$ & $1.10^{\mathrm{a}}$ & $0.89^{\mathrm{a}}$ & $1.21^{\mathrm{a}}$ & $1.60^{\mathrm{a}}$ & $0.95^{\mathrm{a}}$ & $1.18^{\mathrm{a}}$ & $0.76^{\mathrm{a}}$ \\
\hline \multicolumn{10}{|c|}{ Non-essential amino acid } \\
\hline & Aspartate & Serine & Glutamic & Proline & Glycine & Alanine & Cysteine & Tyrosine & \\
\hline T1 & $0.38^{\mathrm{c}}$ & $0.45^{\mathrm{b}}$ & $0.53^{\mathrm{c}}$ & $0.24^{\mathrm{b}}$ & $0.26^{\mathrm{b}}$ & $0.50^{\mathrm{b}}$ & $0.43^{\mathrm{a}}$ & $0.46^{\mathrm{b}}$ & \\
\hline T2 & $0.89^{\mathrm{b}}$ & $0.80^{\mathrm{ab}}$ & $1.12^{\mathrm{b}}$ & $1.35^{\mathrm{a}}$ & $0.76^{\mathrm{a}}$ & $0.78^{a}$ & $0.51^{\mathrm{a}}$ & $0.89^{a}$ & \\
\hline T3 & $1.65^{\mathrm{a}}$ & $1.05^{\mathrm{a}}$ & $1.79^{\mathrm{a}}$ & $1.56^{\mathrm{a}}$ & $0.83^{\mathrm{a}}$ & $0.82^{\mathrm{a}}$ & $0.52^{\mathrm{a}}$ & $0.90^{\mathrm{a}}$ & \\
\hline T4 & $1.45^{\mathrm{a}}$ & $0.89^{\mathrm{ab}}$ & $1.78^{\mathrm{b}}$ & $1.48^{\mathrm{a}}$ & $0.78^{a}$ & $0.89^{a}$ & $0.55^{\mathrm{a}}$ & $0.98^{a}$ & \\
\hline I5 & $1.70^{\mathrm{a}}$ & $1.09^{\mathrm{a}}$ & $1.91^{\mathrm{a}}$ & $1.60^{\mathrm{a}}$ & $0.86^{\mathrm{a}}$ & $0.98^{a}$ & $0.61^{\mathrm{a}}$ & $1.03 \mathrm{a}$ & \\
\hline
\end{tabular}




\section{High resolution scan microscope:}

Images of high-resolution scan microscope show that the biochar has spongy structure and intrapore play a part vital role in getting higher water retention of sand-bio-char mixture. In Fig. 1, Images (a) showed that intra-porosity of bio-char augments plant available water, symptomatic of that high intra-porosity of bio-char will be the majority useful. Some factors are controlling bio-char internal porosity such as feedstock kind, pyrolysis hotness, and charring habitation time, soled to Loading by microorganisms.

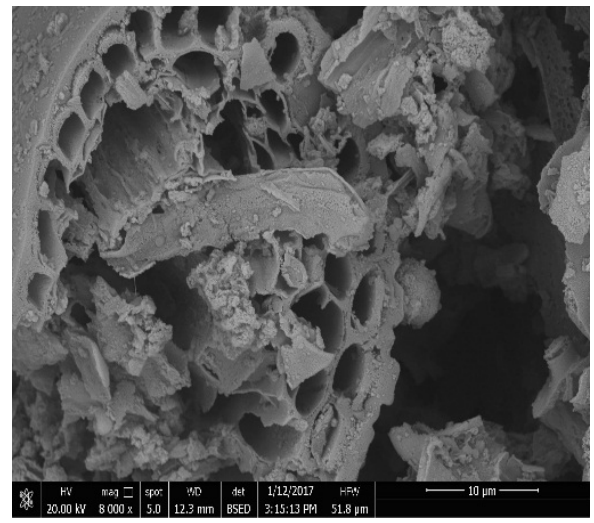

A

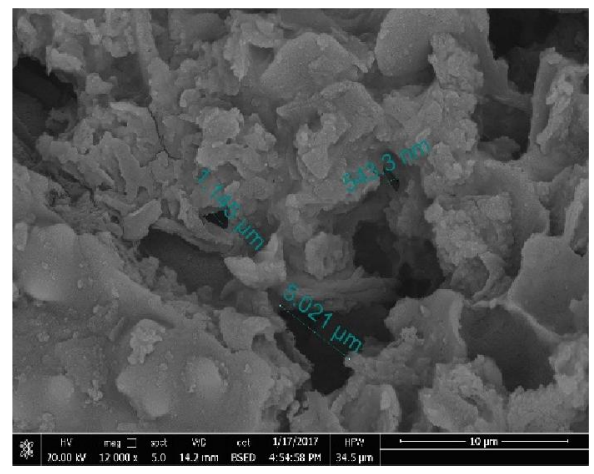

C

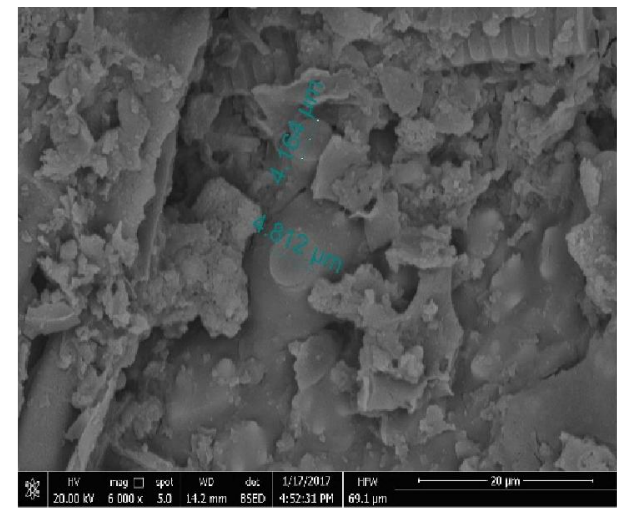

B

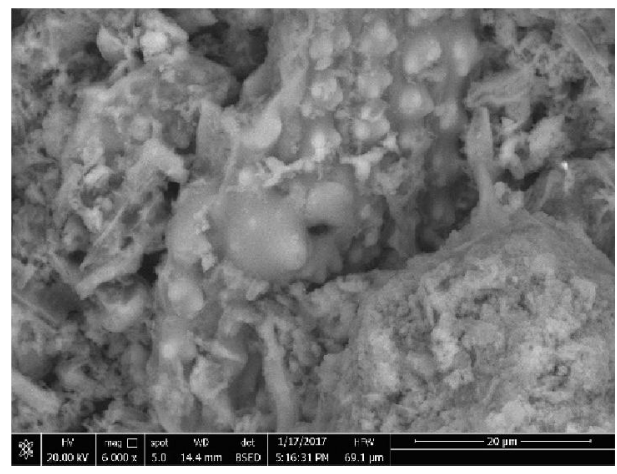

D

Fig. 1: Images (A) spongy structure for biochar, (B) biochar loaded Azotobcter chrococcoum +Bacillus subtilis, (C) Bio-char loaded by Pseudomonas fluorescens and (D), Bio-char loaded algae (Spirulina platensis + Anabaena azollae).

Image (B) showed that biochar was successes for loading by Azotobcter chrococcoum +Bacillus subtilis, meanwhile image (c) illustrated that Pseudomonas fluorescens was loaded on biochar, (D) in addition algae (Spirulina platensis + Anabaena azollae) was grown on biochar. Only Azotobcter chrococcoum and Anabaena azollae were produced Nitrogenase and also all strains were generated Phytohormones which promoted plant growth.

\section{Minerals}

The major nutrients are $\mathrm{Na}, \mathrm{Mg}, \mathrm{P}, \mathrm{S}, \mathrm{Cl}_{2}, \mathrm{~K}$, and $\mathrm{Ca}$ which are classified as macronutrients and the trace elements, are $\mathrm{Cr}, \mathrm{Mn}, \mathrm{Fe}, \mathrm{Co}, \mathrm{Cu}, \mathrm{Zn}, \mathrm{Se}, \mathrm{Mo}$ and $\mathrm{I}_{2}$ (Adotey et al., 2009). Nitrogen, potassium, calcium, magnesium, and sodium which are nutritionally vital were found in practical amount in stevia leaves (Khiraoui et al., 2017). The concentrations of macro and micro elements have been determined in dried leaves.

Table 7 illustrated that T5 (bio-char loaded all strains of biofertilizers) has the highest values for all minerals compared with control. Data revealed that treatments prompted the nutrient contents of nitrogen, phosphorous, potassium, sodium, iron, manganese and zinc over control treatment. The results may be attributed to high content of elements in bio-char especially $\mathrm{N}_{2}, \mathrm{Ca}, \mathrm{K}$, and $\mathrm{Mg}$. Moreover, using chemical and bio-fertilizer included nutrient management is found to boost final yield of Stevia. This is caused by their capability to fasten atmospheric nitrogen (symbiotically and asymbiotically) and transform soil nutrients such as phosphorus, zinc, copper, iron, sulfur from the non-usable to utilizable 
form and decompose organic wastes during biological processes which sequentially liberates elements. The liberated elements can be simply absorbed by plants consequential in an augment in biomass production of stevia plant (Glaser et al., 2002). Furthermore, Vivekanandan et al. (2015) reported that stimulation of plant growth and easiness the movement of elements in the rhizosphere microcosm improve the microbe performance for lowering deterioration resulted in salinity in the environment and augment nutrient uptake from soil to plants via generation of phytohormones by root-colonizing bacteria. Finally, Kang et al. (2014) found that the phosphorus and potassium ion concentrations were significantly superior with PGPR application in comparison with non-PGPR. Anuj et al. (2015) showed that nitrogen, phosphorus, potassium, iron, zinc, copper, and manganese constituents increased significantly in grains by inoculation with cyanobacterial and bacterial strains.

Table 7: Minerals content (mg $100 \mathrm{~g}-1$ ) of dried Stevia (honey leaves).

\begin{tabular}{cccccccc}
\hline $\begin{array}{c}\text { Minerals contents } \\
\text { (mg 100 g-1) }\end{array}$ & Nitrogen & Phosphorus & Sodium & Potassium & Iron & Magnesium Zinc \\
\hline T1 & $584.1^{\mathrm{e}}$ & $323.0^{\mathrm{e}}$ & $114.0^{\mathrm{e}}$ & $756.0^{\mathrm{d}}$ & $50.0^{\mathrm{d}}$ & $356.0^{\mathrm{d}}$ & $0.98^{\mathrm{b}}$ \\
T2 & $638.0^{\mathrm{d}}$ & $353.0^{\mathrm{d}}$ & $125.0^{\mathrm{d}}$ & $970.0^{\mathrm{c}}$ & $54.0^{\mathrm{cd}}$ & $312.0^{\mathrm{e}}$ & $1.34^{\mathrm{b}}$ \\
T3 & $789.0^{\mathrm{c}}$ & $397.0^{\mathrm{c}}$ & $145.0^{\mathrm{b}}$ & $1234.0^{\mathrm{b}}$ & $66.0^{\mathrm{b}}$ & $415.0^{\mathrm{c}}$ & $1.89^{\mathrm{b}}$ \\
T4 & $845.0^{\mathrm{b}}$ & $434.0^{\mathrm{b}}$ & $134.0^{\mathrm{c}}$ & $1689.0^{\mathrm{a}}$ & $59.0^{\mathrm{c}}$ & $489.0^{\mathrm{b}}$ & $3.34^{\mathrm{a}}$ \\
T5 & $950.0^{\mathrm{a}}$ & $453.0^{\mathrm{a}}$ & $216.0^{\mathrm{a}}$ & $1703.0^{\mathrm{a}}$ & $75.0^{\mathrm{a}}$ & $548.0^{\mathrm{a}}$ & $4.30^{\mathrm{a}}$ \\
\hline
\end{tabular}

\section{Fatty acids}

Table 8 illustrated that all fatty acids were affected by all treatments. (T5) (bio-char loaded all strains of bio-fertilizers) has a highest value in fatty acid comparison with other treatments. The results were harmony with Bernal et al. (2011) and Atteh et al. (2011) noticed that palmitic acid (27.51-29.5), oleo palmitic acid (1.27-3.0), stearic acid (1.18- 4.0), oleic acid (4.36- 9.9), linoleic acid (12.40-16.8), and linolenic acid (21.59-32.6) in oil stevia leaves. All values of fatty acids determined as $\mathrm{g} / \mathrm{l}$.

Table 8: The composition of fatty acids contents (g 100 g-1) in oil from Stevia leaves.

\begin{tabular}{ccccccc}
\hline Fatty acids & Palmitic acid & Oleopalmitic acid & $\begin{array}{c}\text { Stearic } \\
\text { acid }\end{array}$ & Oleic acid & Linolic acid & Linolenic acid \\
\hline T1 & $20.91^{\mathrm{c}}$ & $1.12^{\mathrm{b}}$ & $1.10^{\mathrm{b}}$ & $4.35^{\mathrm{b}}$ & $11.89^{\mathrm{e}}$ & $19.90^{\mathrm{d}}$ \\
T2 & $23.76^{\mathrm{b}}$ & $1.26^{\mathrm{b}}$ & $1.20^{\mathrm{b}}$ & $4.70^{\mathrm{b}}$ & $12.67^{\mathrm{d}}$ & $21.80^{\mathrm{c}}$ \\
T3 & $25.90^{\mathrm{b}}$ & $2.34^{\mathrm{a}}$ & $3.45^{\mathrm{a}}$ & $8.90^{\mathrm{a}}$ & $14.55^{\mathrm{c}}$ & $30.84^{\mathrm{b}}$ \\
T4 & $26.43^{\mathrm{b}}$ & $2.45^{\mathrm{a}}$ & $3.65^{\mathrm{a}}$ & $9.12^{\mathrm{a}}$ & $15.98^{\mathrm{b}}$ & $31.67^{\mathrm{ab}}$ \\
T5 & $29.21^{\mathrm{a}}$ & $2.95^{\mathrm{a}}$ & $3.90^{\mathrm{a}}$ & $9.80^{\mathrm{a}}$ & $16.90^{\mathrm{a}}$ & $32.40^{\mathrm{a}}$ \\
\hline
\end{tabular}

\section{Vitamins}

Table 9 revealed that the contents of vitamin $\mathrm{C}$ in the leaf extracts were significantly higher for $\mathrm{T} 5$ (bio-char loaded all strains of biofertilizers) tracked by T1, T2, T3 and T4. The same trend was occurred for the same category of treatments in vitamin B2 values. In addition, the components of vitamins B6, niacin, thiamin was neglected. Moreover, leaves of Stevia, was found to be folic acid as the foremost compound against all vitamins and took the same tracking of treatments, followed by vitamin $\mathrm{C}$, and vitamin B2.

Table 9: Water soluble vitamins of S. rebaudiana leaf (mg $100 \mathrm{~g}-1$ dry basis of extract).

\begin{tabular}{ccccccc}
\hline Vitamins & Vitamin C & Vitamin B2 & Vitamin B6 & Folic acid & Niacin & Thiamin \\
\hline T1 & $13.32 \mathrm{c}$ & $0.31 \mathrm{~b}$ & 0.00 & $45.78 \mathrm{c}$ & 0.00 & 0.00 \\
$\mathrm{~T} 2$ & $13.56 \mathrm{bc}$ & $0.34 \mathrm{ab}$ & 0.00 & $48.90 \mathrm{~b}$ & 0.00 & 0.00 \\
$\mathrm{~T} 3$ & $14.29 \mathrm{abc}$ & $0.41 \mathrm{ab}$ & 0.00 & $52.59 \mathrm{a}$ & 0.00 & 0.00 \\
$\mathrm{~T} 4$ & $14.58 \mathrm{ab}$ & $0.43 \mathrm{a}$ & 0.00 & $53.34 \mathrm{a}$ & 0.00 & 0.00 \\
$\mathrm{~T} 5$ & $14.90 \mathrm{a}$ & $0.44 \mathrm{a}$ & 0.00 & $54.12 \mathrm{a}$ & 0.00 & 0.00 \\
\hline
\end{tabular}

\section{Conclusion}

Forasmuch the pharmaceutical momentousness of Stevia plants as a substituted sweaty material of sugar to avoid the risk and deterioration of human health, the agricultural scientists oriented their efforts to ameliorate and maximize the productivity of honey leaves (Stevia) plants. In addition to lowering cost of productivity, bio-fertilizers immobilized by bio-char technique was the promising proposal for 
diminishing the hazardous chemical fertilizers and maintaining of clean environment. Immobilization technique of bio-fertilizers on bio-char play an advantageous function in sandy soil because of excreting polysaccharides which aggregate the particles of soil, improve the porosity of the soil and facilitate the transformation of nutrient elements to the plant.

\section{References}

Abd El-Aal, Azza, 2013. Characterization of Anabaena azollae isolated from Azolla pinnat. Egypt. J. Agric. Res., 91(3): 801-807.

Abd El-Malak, Y. and Y.Z. Ishac, 1968. Evaluation methods used in counting Azotobacter.J.Appl.Bact., 331:269-275.

Adotey, D., Y. Serfor-Armah, J. Fianko and P. Yeboah, 2009. Essential elements content in core vegetables grown and consumed in Ghana by instrumental neutron activation analysis. African Journal of Food Science, 3: 243-249.

Aladakatti, Y.R., Y.B. Palled., M.B. Chetti., S.I. Halikatti., S. C. Alagundagi., P.L. Patil., V.C. Patil and A.D. Janawade, 2012. Effect of nitrogen, phosphorus and potassium levels on growth and yield of stevia (Stevia rebaudiana Bertoni). Karnataka. J. Agric. Sci., 25(1): 25-29.

Amal, Z., S. Hegazi, S.M. Mostafa and M.I. Hamdino, 2010. Influence of Different Cyanobacterial Application Methods on Growth and Seed Production of Common Bean under Various Levels of Mineral Nitrogen Fertilization, 8(11):183-194

Association of Official Analytical Chemist International, 2000. Official Methods of Analysis of the Association of Official Analytical Chemists International $17^{\text {th }}$ edn. Association of Official Analytical Chemists International, Arlington, VA, USA.

Atteh, J., O. Onagbesan, K. Tona, J. Buyse, E. Decuypere, and J. Geuns, 2011. Potential use of Stevia rebaudiana in animal feeds. Archivos de zootecnia, 60(229): 133-136.

A.O.A.C., 1970. Official Methods of Analysis of the Association of Official Agricultural Chemists (A.O.A.C.) Twelf 14 editation, Washington. D.C. 170-176.

Anuj, R., S.R. Kabil, Sh. Verma, A. Adak, M. Pa, S. Shivay, P.R. Radha and L. Nain, 2015. Prospecting plant growth promoting bacteria and cyanobacteria as options for enrichment of macro- and micronutrients in grains in rice-wheat cropping sequence. Cogent Food and Agriculture, 1: 1-16.

Bargaz, A., K. Lyamlouli, M. Chtouki, Y. Zeroual and D. Dhiba, 2018. Soil Microbial Resources for Improving Fertilizers Efficiency in an Integrated Plant Nutrient Management System. Front. Microbiol., 9:1606.

Bernal, J., J. Mendiola, E. Ibáñez, and A.E. Cifuentes, 2011. Advanced analysis of nutraceuticals. Journal of Pharmaceutical and Biomedical Analysis, 55: 758-774.

Brewer, C.E., V.J. Chuang, C.A. Masiello, H. Gonnermann, X. Gao, and B. Dugan 2014. New approaches to measuring biochar density and porosity. Biomass Bioenergy, 66: 176-185.

Brown and K.R. Islam, 2010. Growth, yield and nitrate accumulation of irrigated carrot and okra in response to nitrogen fertilization. In Pakistan Journal of Botany, 42(4): 2513-2521.

Cabrera-Mesa A., and K.A. Spokas, 2011. Impacts of biochar (black carbon) additions on the sorption and efficacy of herbicides. Herbicides and the Environment. InTech, Croatia, pp. 315-340. 44, $1247-1253$.

Das K., D. Raman, N. Thippenahalli and N. S. Shivananda, 2007. Influence of bio-fertilizers on the biomass yield and nutrient content in Stevia rebaudiana Bert. grown in Indian subtropics. Journal of Medicinal Plants Research Vol. 1(1), pp. 005-008

Fales, H. M. and T. M. Jaouni, 1973. Simple device for preparing ethereal diazomrthane without restoring to Codisitillation. Anal. Chem, 45:2302-2303.

Gisleine EC, HA. Abdol, CA. Caudio, de AFF. Letícia, T. Gilson, HT. Mirian, EF. Wilson, and BB. Roberto, 2006. Investigation of the tolerability of oral Stevioside in Brazilian hyperlipidemic

Patients.Braz Arch Biol Technol., 49: 583-587.

Glaser, B., J. Lehmann and W. Zech, 2002. Ameliorating physical and chemical properties of highly weathered soils in the tropics with charcoal-A Review. Biol. Fertile. Soils, 35: 219-230.

Godlewska, K., I. Michalak, P. Pacyga, S. Baśladyńska, and K. Chojnacka., 2019. Potential applications of cyanobacteria: Spirulina platensis filtrates and homogenates in agriculture. World J Microbiol Biotechnol., 35(6): 80. 
Hassan, A.Z.A., M.M. Abdelwahab, G. Turky and S. Gehan, 2020. Rice husk derived biochar as smart material loading Nano nutrients and microorganisms. Bulgarian Journal of Agricultural Science, 26 (No 2) 2020, 309-322.

Ismail, E.G., W.M. Walid, K. Salah, and E.S. Fadia, 2014. Effect of manure and bio-fertilizers on growth, yield and silymarin content and protein expression profile of Slibummarianum. Adv. Agric.Biol., 1(1):36-44.

Jackson, M.L., 1973. Soil Chemical Analysis. New Delhi: Printice-Hall of India. Privat Limited, New Delhi. Text book.pp. 144-197, 381.

Kamal-Alahmad, 2018. Stevia rebaudiana Bertoni: Description and Chemical Composition. International Journal of Agriculture Innovations and Research Volume 7, Issue 2

Kang, S.M., M. Waqas, A.L. Khan and I.J. Lee, 2014. Plant growth promoting rhizobacteria: potential candidates for gibberellins production and crop growth promotion. In: Miransari M, editor. Use of microbes for the alleviation of soil stresses. New York: Springer, 1-19.

Khiraoui, A., M. Bakha, F. Amchra, S. Ourouadi, A. Boulli, C. Al-Faiz and A. Hasib, 2017. Nutritional and biochemical properties of natural sweeteners of six cultivars of Stevia rebaudiana Bertoni leaves grown in Morocco. Journal of Materials and Environmental Science, 8 (3): 1015-1022.

Kim, I., M. Yang, O. Lee, and K. Nam-Suk, 2011. The antioxidant activityand the bioactive compound content of Stevia rebaudiana water extracts. LWT-Food Sci. Technol., 44:1328-1332.

King, E.O., M.K. Ward and D.E. Raney, 1954. Two simple media for the demonstration of phycocyanin and fluorescen J.Lab.CIM. Med.44: 301-307.

Kinney, T.J., CA. Masiello, B. Dugan, WC. Hockaday, MR. Dean, K. Zygourakis, 2012. Hydrologic properties of biochars produced at different temperatures. Biomass and Bioenergy, 41:34-43.

Kloss, S., F. Zehetner, A. Dellantonio, R. Hamid, F. Ottner, V. Liedtke, M. Schwanninger, M.H. Gerzabek and G. Soja, 2012. Characterization of slow pyrolysis biochars: effects of feedstock's and pyrolysis temperature on biochar properties. J. Environ. Qual.41: 990-1000.

Larue, T.A. and W.G.W. Kurz, 1973. Estimation of Nitrogenase Using a Colorimetric Determination for Ethylene1. Journal of Plant Physiol., 51: 1074-1075.

Li, J., C.W. Ee and B. Sohn, 2013. Effect of ammonium-and potassium-loaded zeolite on kale (Brassica albolabrin) growth and soil property.In American Journal of Plant Sciences, 4(10): 1976.

Mohammad, M., U. Mohammad, M. Sher, A. Habib, A. EtIqbal, 2007. In vitro clonal propagation and biochemical analysis of field established Stevia rebaudiana Bertoni. Pakistan J Bot. 39 2467-2474.

Mubashir, M., K. Malik, A.A., T.M. Ansari, S. Wright, M.V. Nilde A.B. Di, R.C. Maria, C. Daniela, P.C. Mariagrazia, B. Antonio, S. Milena and F. Zina, 2017. The role of Plant Growth Promoting Bacteria in improving nitrogen use efficiency for sustainable crop production: a focus on wheat. AIMS Microbiology, 3(3): 413-434.

Nornai, R., 1982. Formula for determination of chlorophyllus pigments extracted with N.N dimethyl formamide. Plant Physiol., 69:137 1381.

Panel, B.S., G. Likun, B. Lijun, Z. Shiwei, W. Yingxue, B. Zhihui, Z. Guoqiang and Z. Xuliang, 2020. Application of biofertilizer containing Bacillus subtilis reduced the nitrogen loss in agricultural soil. Soil Biology and Biochemistry, 148: 107911

Paz-Ferreiro, J., S.L. Fu, A. Mendez, and G. Gasco, 2014. Interactive effects of biochar and the earthworm Pontoscolex corethrurus on plant productivity and soil enzyme activities. J. Soils Sed. 14: 483-494.

Peach, K. and M.V. Tracy, 1956. Modern methods of plant analysis. Vol. 1. Springier. Velay Berlin, $643 p$.

Piromyou, P., B. Buranabanyat, P. Tantasawat, P. Tittabutr, N. Boonkerd, and N. Teaumroong, 2011. Effect of plant growth promoting rhizobacteria (PGPR) inoculation on microbial community structure in rhizosphere of forage corn cultivated in Thailand.European Journal of Soil Biology, 47:44-54.

Plamer, M.V., R. Hogan and P.F. Wareing, 1981. Cytokinins metabolism Phaseolusvuglaris L. identification of endogenous cytokinins and metabolism of (8-C14) dihrozeatin in stems of decapitated plants.Palnta, 153:297-302.

Prathibha, K.S. and K.G. Siddalingeshwara, 2013. Effect of plant growth promoting Bacillus subtilis and Pseudomonas fluorescence as Rhizobacteria on seed quality of sorghum. International Journal of Current. Microbiology and. Applied Science, 2(3): 11-18. 
Prosky, L., 2001. What is dietary fibre? A new look at the definition. Advanced dietary fibre technology, 63-73.

Qui, X.X., D.F. Huang, S.X. Cai, F. Chen, Z.G. Ren and Y.C. Cai, 2000. Investigations on vegetables pollution and pollution sources and its control in Fuzhou, Fujian Province. Fujiana J Agric.Sci., 15: $16-21$.

Rai, C., G.C. Majumdar and S. De., 2013. Primary Clarification of Stevia Extract: A Comparison between Centrifugation and Microfiltration. Separ Sci. Technol., 48:113:121

Reddy, K., T. Xie, and S. Dastgheibi, 2014a. Evaluation of biochar as a potential filter media for the removal of mixed contaminants from urban storm water runoff. J. Environ. Eng., 04014043.

Reddy, K.R., E.N. Yargicoglu, D. Yue, Y. Aghoubi, 2014b. Enhanced microbial methane oxidation in landfill cover soil amended with biochar. J. Ggeotech. Govern. Eng., ASCE 140 (9).04014047.

Richa, K., P. Jyoti, G. Shilpi, V. Himanshu, T. Himanshu, K. Pradeep and K. Rajan, 2019. Efficiency of biofertilizers in increasing the production potential of cereals and pulses: A review. Journal of Pharmacognosy and Phytochemistry, 8(2): 183- 188.

Richards, L.S., 1954. Diagnosis and Improvement of Saline and Alkaline Soils. U.S. Dept. Agric. Handbook No. 60.

Rippka, R., J. Deruelles, J.B. Waterbury, M. Herdman, and R.Y. Stanier, 1979. Generic assignments, strain histories and properties of pure cultures of cyanobacteria. J. Gen. Microbiol., 111: 1-61.

Sankhala, A., A.K. Sankha, B. Bhatnagar and A. Singh, 2005. Nutrient composition of less familiar leaves consumed by the tribals of Udaipur region.Journal of Food Science and Technology mysore, 42(5): 446-448.

Sarwar, G., N. Hussain, H. Schmeisky, S. Muhammad, M. Ibrahim, and E. Safdar, 2007. Use of compost an environment friendly technology for enhancing rice-wheat production in Pakistan. In Pakistan Journal of Botany, 39(5): 1553-1558.

Serio, L., 2010. La Stévia, une alternative au sucreet à l'aspartame. Phytothérapie; 8: 26-32.

Silva, F., A.S.E. de, and C.A.V. de Azevedo, 2009. Principal components analysis in the software costate-statistical attendance. In: World Congress on Computers in Agriculture, 7, Reno-NV-USA: American Society of Agricultural and Biological Engineers.

Singh, D.P., K. Meenakshi, H.G. Prakash, G.P. Rao, and S. Solomon, 2019. Phytochemical and Pharmacological Importance of Stevia: A Calorie-Free Natural Sweetener. In "Sugar Tech.: An International Journal of Sugars Crops and Related Industries". Edited by Salmon, S

Tadhani, M. and R. Subhash, 2006. Preliminary Studies on Stevia rebaudiana Leaves: Proximal Composition, Mineral Analysis and Phytochemical Screening. J Medical Sci., 6: 321-326.

Uchimiya, M., L.H. Wartelle, K.T. Klasson, C.A. Fortier and I.M. Lima, 2011. Influence of pyrolysis temperature on biochar property and function as a heavy metal sorbent in soil. J. Agric. Food Chem., 59: 2501-2510.

Vivekanandan, M., R. Karthik, and A. Leela, 2015. Improvement of crop productivity in saline soils through application of saline-tolerant rhizosphere bacteria - Current Perspective. International Journal of Advanced Research, 3 (7): 1273-1283.

Varma, A.K., R. Shankar, P. Mondal, P.K. Sarangi, N. Sonil, and M. Pravakar, 2018. A Review on Pyrolysis of Biomass and the Impacts of Operating Conditions on Product Yield, Quality, and Upgradation. Recent Advancements in Biofuels and Bioenergy Utilization. Springer, In, pp. 227 259.

Yoti, J., M. Kaur, V. Mishra, and A. Mittal, 2018. Sweet Future of Stevia: A Magical Sweetener. Asian J. Pharm. Clin. Res., 11(2): 36-42.

Zahra, Z., H.C. Da, L. Heayyean and P. Amna, 2020. Cyanobacteria: Review of Current Potential and Applications. Environments 7, 13

Zarrouk, C., 1966. Contribution a l'etude d'une Cyanobacterie: Influence de divers facteurs physiques et chimiques sur la croissance et al photosynthese de Spirulina maxima (Setch. ET Gardner) Geitler. Ph. D. Thesis, University of Paris, France.

Zayova, E., S. Ira, G. Maria, P. Maria, and D. Lyudmila, 2013. Antioxidant activity of in vitro propagated Stevia rebaudiana Bertoni plants of different origins. Turk. J. Biol., 37: 106-113

Zhu, X., B. Chen, L. Zhu, and B. Xing, 2017. Effects and mechanisms of biochar-microbe interactions in soil improvement and pollution remediation: A review. Environmental Pollution, 227: 98-115. 